\title{
Sistem Peradilan Pidana Berkeadilan melalui Pendekatan Kontrol dalam Proses Penegakan Hukum
}

\author{
Hasuri \\ Fakultas Ilmu Sosial, Ilmu Politik dan Ilmu Hukum, Universitas Serang Raya, Serang. \\ Email : majalah.assaadah@gmail.com
}

Info Artikel:

| Diterima: 19 Desember 2019

| Disetujui: 30 Desember 2019

| Dipublikasikan: 31 Desember 2019

\begin{abstract}
Justice in the criminal justice system is a static and dynamic in accordance with the space, time and conditions of criminal acts, justice has legal aspects in criminal justice. Understanding justice in the criminal justice system will be found differences in justice that are relatively in accordance with criminal acts and the consequences of these criminal acts. The clean and authoritative administration of justice is the ideals of the judiciary in Indonesia and the hope of seeking justice, the face of the judiciary forms a fair criminal justice system if under ideal conditions, sometimes the criminal justice system does not escape the pressures of the interests of those who want to polarize the law in accordance with a sense of justice constructed by law enforcement as a sub-system of the judiciary body. Normative law enforcement is a series of actions to maintain material law that has been violated by legal subjects in general, law enforcement in the criminal justice system has unique characteristics and procedures in accordance with the legal system adopted and continuously shifts in balance through a renewed legal system. Relevant issues to be examined are: What is the basic idea of a fair trial, How to approach the control of the criminal justice system as an alternative to distributing justice. This study uses a constructivist paradigm with Non-Doctrinal Approach Method or socio-legal research with Qualitative methods, the research specifications are using analytical descriptive, the main data types in this study are field data and are supported by library data, data analysis methods are using Juridical-Qualitative data. For field data validation using interview and observation techniques. The results of the research and discussion in this study are in accordance with the problems that were the focus of the study found the following matters: First, the lack of harmony between the legal system and the criminal law enforcement system has an impact on the basic idea of the criminal justice system. Second, control in the criminal justice system is part of the transformation and reform of the legal system in the criminal justice system.
\end{abstract}

Keywords: Control of the Criminal Justice Syste; Law Enforcement; 


\begin{abstract}
Abstrak
Keadilam dalam sistem peradilan pidana merupakan suatu yang statis dan dinamis sesuai dengan ruang, waktu dan kondisi perbuatan pidana, keadilan memiliki segi-segi hukum dalam peradilan pidana. Memaknai keadilan dalam sistem peradilan pidana akan ditemukan perbedaan-perbedaan keadilan yang relatif sesuai dengan perbuatan pidana dan akibat dari perbuatan pidana tersebut. Penyelenggaraan peradilan yang bersih dan berwibawa merupakan cita-cita dari badan peradilan di Indonesia dan harapan pencari keadilan, wajah peradilan tersebut membentuk sistem peradilan pidana yang fair bila dalam kondisi ideal, tak kadang sistem peradilan pidanapun tidak luput dari tekanan-tekanan kepentingan pihak-pihak yang ingin mempolarisasikan hukum sesuai dengan rasa keadilan yang di konstruksikan penegak hukum sebagai sub sistem badan peradilan. Penegakan hukum secara normatif adalah serangkaian perbuatan untuk mempertahankan hukum materil yang telah dilanggar oleh subjek hukum pada umumnya, penegakan hukum dalam sistem peradilan pidana memiliki ciri dan tata cara yang khas sesuai dengan sistem hukum yang dianut dan terus menerus bergeser dengan penuh keseimbangan melalui pembaharuan sistem hukum.Permasalahan yang relevan untuk dikaji adalah: Bagaimana ide dasar peradilan yang berkeadilan, Bagaimaan pendekatan control sistem peradilan pidana sebagai alternatif memndistribusikan keadilan. Penelitian ini menggunakan paradigma constructivist dengan Metode Pendekatan Non Doktrinal atau socio-legal research dengan metode Kualitatif, sepesifikasi penelitian menggunakan deskriptif analitis, jenis data utama dalam penelitian ini data lapangan dan didukung data kepustakaan, metode analisis data menggunakan Yuridiskualitatif. Untuk validasi data lapangan menggunakan teknik wawancara dan observasi.Hasil penelitian dan pembahasan dalam penelitian ini sesuai dengan permasalahan yang dijadikan fokus penelitian didapati hal-hal sebagai berikut: Pertama, tidak terdapat keselarasan antara sistem hukum dan sistem penegakan hukum pidana berdampak pada ide dasar dari sistem peradilan pidana.Kedua, kontrol dalam sistem peradilan pidana merupakan bagian dari trasnformasi dan reformasi sistem hukum dalam sistem peradilan pidana.
\end{abstract}

Kata Kunci : Kontrol Sistem Peradilan Pidana; Penegakan Hukum; 


\section{A. PENDAhULUAN}

Tujuan utama peradilan pidana adalah memutuskan apakah seseorang bersalah atau tidak, dilakukan melalui prosedur yang diikat oleh aturan-aturan ketat tentang pembuktian dan mencakup semua batas-batas konstitusional yang berakhir pada proses pemeriksaan di pengadilan. Proses yang berkaitan dengan syarat-syarat dan tujuan "peradilan yang fair" (due proces), melalui antara lalin asas praduga tidak bersalah, cara kerja yang benar dimana seseorang yang diduga mengalami pemeriksaan atau pengadilan jujur dan terbuka. Proses itu harus sungguh-sungguh, tidak pura-pura atau bukan kepalsuan yang tererncana, mulai dari penangkapan sampai penjatuhan pidana harus bebas dari paksaan atau ancaman sehalus apapun. $^{1}$

Due procces dan crime control merupakan modal-model normatif peradilan, yang memiliki tujuan tertentu dan berbeda keduanya secara fundamental, baik dari persoalan nilai atau kepentingan-kepentingan yang hendak dicapai. ${ }^{2}$ Crime Control model.

\footnotetext{
Menurut Abraham Blumberg, dalam bukuknya: Criminal Justice, dikatakan,

"The Metaliculous requisites and gods of due process include, among other thing a presumption of innocence and truly adversay proceding in the course of which an accused person recixd a full fair, and open judicial bearing or trail. The beaning must be areal one, not a sbarm or some contrived prelense...."

Lihat Abraham Blumberg, Criminal Justice, Published by Burns and MacEachern Ltd, Toronto 1970, hal. 4-5

2 Hebert Packer, dalam The Limits of Criminal Sanction, menguraikan mengenai model-model nirmatif dari proses pemeriksaan pidana. Dikatakan "bahwa suatu pendekatan pragmatis atas pertanyaan mendasar mengenai tujuan baik dari adanya hukum pidana memerlukan suatu penyelidikan secara umum tentang apakah suatu pidana merupakan suatu kendali sosial yang memiliki kecepatan tinggi atau rendah dalam penyelidikan lanjutan dan bersifat khusus mengenai kemampuannya untuk
}

Lebih menekankan cara kerja efisien, cepat dengan maksud untuk memperoleh pengakuan, sementara due proces mengutamakan kesusilaan dan kegunaan sanksi pidana. $^{3}$ Proses pemeriksaan perkara

mengatasi perilaku anti sosial, bertitik tolak dari kedua perasyarat tersebut memerlukan suatu pemahaman mengenai "criminal procces". Satusatunya cara untuk melaksanakan tugas tersebut diatas adalah dengan mengabstaraksi kenyataan dan membangun sebuah model. Model yang hendak dibangun adalah model (1). Yang memiliki kegunaan sebagai indeks dari satu pilihan nilai masa kini tentang bagaimana suatu sistem diimplementasikan; (2). Dan sebuah model yang terbentuk dari usaha untuk membedakan secara tajam hukum dalam buku teks dan mengungkapkan seakurat mungkin apa yang sedang terjadi dalam kehidupan nyata sehari-hari; dan (3) sebuah model yang dapat dipergunakan untuk mengenali secara eksplisit pilihan nilai yang melandasi rincian suatu "criminal process". Bentuk model yang cocok untuk mencapai ketiga hal tersebut adalah modelmodel negatif. Pacjer menegaskan bahwa akan ada lebih dari satu model normatif dari hukum pidana. Kedua model ini disebut the due procees model dan the crime control model". Lihat Herbert Packer, The Limits of the Criminal Sanction, Stanford University Perss, Stanford Calivornia, 1968, hal. 152-158.

3 Nilai-nilai yang melandasi crime control model adalah:

1. Tindakan represif terhadap suatu tindakan kriminal merupakan fungsi terpenting dari suatu proses peradilan;

2. Perhatian utama harus ditunjukan kepada efisiensi dari suatu penegakan hukum untuk menyeleksi tersangka, meentapkan kesalahannya dalam menjamin atau melindungi hak tersangka dalam proses peradilannya;

3. Proses kriminal penegakan hukum harus dilaksanakan berdasarkan cepat, dan tuntas dan model yang dapat mendukung proses penegakan hukum tersebut adalah model adminsitarsi dan menyerupai model manajerial;

4. "asas praduga tidak bersalah" akan menyebabkan sistem ini dilaksanakan secara efisien;

5. Proses menetapkan hukum harus menitik beratkan kepada kualitas temuan-temuan fakta adminstratif, oleh karena temuan tersebut akan membawa ke arah pemebasan seorang tersangka dari penuntutan atau kesediaan tersangka menyatakan dirinya bersalah. 
pidana yang dilandasi oleh due process merupakan bentuk birokrasi administrasi, di Indonesia hal tersebut diwujudkan melalui aturan khusus, dikenal sebagai Kitab UndangUndang Hukum Acara Pidana (KUHAP). ${ }^{4}$

Ada empat faktor yang sangat mempengaruhi penegakan hukum dalam suatu negara demokrasi. Pertama, hukum itusendiri, baik dalam pengertian substansial dari suatu peraturan perundang-undangan maupun hukum formal untuk menegakkan hukum material. Kedua, profesionalisme aparat penegak hukum. Ketiga, sarana dan prasarana yang cukup memadai. Keempat, adalah persepsi masyarakat terhadap hukum itu sendiri. ${ }^{5}$ Keempat faktor tersebut antara satu dan lainnya saling mempengaruhi. Sebagai misal: guna menunjang profesionalisme aparat penegak hukum, sudah

Adapun Nilai-nilai melandasi due procces model adalah:

1. Kemungkinan adanya faktor kelalaian yang sifatnya manusiawi, menyebabkan model ini menolak cara untuk menetapkan secara definitif seseorag. Model ini hanya mengutamakan "formal adjudicative" dan "adversary fact finding" hal ini berarti dalam setiap kasus tersangka harus memperoleh hak penuh untuk mengajukan pembelaannya;

2. Model ini menekankan kepada pencegahan dan menhapuskan sejauh mungkin kesalahan mekanisme administratif;

3. Model ini bertitik tolak dari nilai bersifat anti terhadap kekuasan sehingga memegang teguh doktrin legal guilt;

4. Gagasan persamaan dimuka hukum diutamakan;

5. Due procces model lebih mengutamakan kesusilaan dan kegunaan sanksi pidana.

Lihat Romli Atmasasmita, Sistem Peradilan Pidana, Perspektif Eksistensialsime, Binacipta Bandung, 1996. Hal. 19-20.

4 Mardjono Reksodipoetro, Sistem Peradilan Pidana Indonesia (melihat kepada kejatahan dan penegakan hukum dalam batas-batas toleransi) Pidato Pengukuhan Penerimaan Jabatan Guru Besar tetap dalam Ilmu Hukum pada Fakultas Hukum Universitas Indonesia 1993, hal 11-12

5 Soerjono Soekanto, Efektifitas Hukum dan Peran Sanksi, Remaja Karya, 1985, Hal 27. barang tentu tidak semata-mata bergantung pada kualitas sumber daya manusia semata, namun sistem yang diciptakan pun turut mempengaruhinya. Terlebih lebih jika kita berbicara dalam sistem peradilan pidana, maka yang menjadi sorotan tidak hanya polisi semata sebagai penjaga pintu gerbang dari sistem tersebut, tetapi juga kita akan menyinggung pihak-pihak yang terkait dalam sistem peradilan pidana itu sendiri seperti hakim, jaksa, pengacara dan satu yang hampir selalu dilupakan namun memegang peranan penting yaitu petugas lembaga pemasyarakatan.

Dalam konteks penegakan hukum di Indonesia, selamakurang lebih 40 tahun tidaklah dapat dipungkiri bahwa berdasarkan realitas empiris sangatlah memprihatinkan. Sebab dalam sejarah kehidupan bangsa Indonesia telah mencatat bahwa selama tahapan terakhir dari sejarah politik dan ketatanegaraan di Indonesia, disadari atau tidak, diakui atau tidak, telah terjadi pembusukan hukum. ${ }^{6}$ Dengan demikian tidaklah berlebihan apayang dikemukakan oleh Joyceline M. Pollock “..... many people referto the criminal justice system as the "criminal injustice system" becauseof perception that practices in the Nation's courtrooms do not necessarily conform to the ideals of justice..... ${ }^{7}$

Secara sederhana sistem peradilan pidana adalah proses yangdilakukan oleh negara terhadap orang-orang yang melanggar

6 Istilah 'pembusukan hukum' pertama kali dikemukakan oleh J.E. Sahetapy. Lihat selanjutnya dalam: Sigit Riyanto dan Eddy O.S. Hiariej,2001, "Fungsi Polisi Dalam Sistem Peradilan Sipil Pasca Pemisahan TNI- Polri" Mimbar Hukum, Majalah Berkala Fakultas Hukum UGM, hal.127.

7 Muladi, 2005, Hak Asasi Manusia: Hakekat, Konsep Dan ImplikasinyaDalam Perpektif Hukum dan Masyarakat, Refika Aditama, hlm. 99. 
hukumpidana. Proses itu dimulai dari kepolisian, kejaksaan dan akhirnya pengadilan. Sebagaimana yang diungkapkan Carvadino dan Dignan bahwa sistem peradilan pidana adalah "A term covering all thoseinstitution which respond officially to the commission of offences, notablythe police, prosecution authorities and the court", Dengan kata lain, sistem peradilan pidana seperti yang telah diutarakan di atas, tidak hanya mencakup satu institusi tetapi berkaitan erat dengan beberapa institusi negara yang menurut Feeney pekerjaan aparat penegak hukum yang satu akan memberikan dampak dan beban kerja kepada aparat penegak hukum yang lain. Hebert L. Packer dalam The Limitsof The Criminal Sanction mengatakan bahwa para penegak hukum dalam sistem peradilan pidana adalah integrated criminal justice system yang tidak dapat dipisahpisahkan. Artinya, antara tugas penegak hukum yang satu dengan lainnya saling berkaitan.

Sampai saat ini, masih kita rasakan bahwa peradilan yang dihormati dan dipercaya oleh publik itu masih sangat jauh dari harapan. Ada banyak hal yang masih harus dilakukan agar kondisi peradilan yang tidak dihormati dan tidak dipercaya publik dewasa ini bisa kita hilangkan. Tidak terdudukannya sistem peradilan pidana yang berkeadilan dengan baik dan tidak dapat dihindari sistem peradilan terus bergeser dan bergerak sesuai peradaban dan hukum positif belum diikuti dengan pembaharuan. Diperlukan penataan kembali ide dasar peradilan yang berkeadilan dan diperlukan pendekatan kontrol sistem peradilan pidana sebagai alternatif mendistribusikan keadilan.

8 Cavadino Michael dan Dignan James, The Penal Sistem An Introduction, 1997, SAGE Publication Ltd. hlm. 7.

\section{B. METODE PENELITIAN}

Penelitian menggunakan pendekatan sosio legal (socio-legal reseach). Melalui pendekatan ini, obyek hukum diposisikan dalam konteks kemasyarakatan yang luas dengan tidak menempatkan bahan terberi yang terisolasi dari kebudayaan (sistem berfikir, sistem pengetahuan) dan relasi kekuasaan diantara para perumus hukum, penegak hukum, para pihak dan masyarakat luas. ${ }^{9}$ Pemahaman bahwa hukum adalah sebatas seperangkat norma yang terlepas dari kesatuan sosial hanya akan menafikan keterkaitan hukum sebagai norma dari basis sosial tempat lahirnya hukum dan tempat bekerjanya hukum. Melalui pendekatan ini, pengkajian dilakukan dengan mendeskripsikan substansi norma-norma hukum dan realitas sosial, serta keterkaitan di antara kedua obyek kajian tersebut. Penelitian socio-legal $^{10}$ yang bertolak dari paradigma konstruktivisme merupakan suatu proses yang tidak pernah berhenti untuk menemukan nilainilai kebenaran. Penelitian ini tidak lagi mengkotak-kotakkan bidang ilmu baik sosial maupun ilmu hukum melainkan penelitian socio-legal sebagai aktivitas sosial yang integreted. Penelitian ini tidak lagi melihat hukum sebagai realitas otonom, obyektif, netral, imparsial, dan dapat digeneralisasikan. Penelitian ini bertujuan untuk terus menerus membangun atau merekonstruksi hukum yang

9 Sulistyowati Irianto, memperkenalkan studi Sosiolegal dan Implikasi Metodelogisnya dalam Metode Penelitian Hukum, Konstelasi dan Refleksi, Editor Sulistyowati Irianto dan Shidarta, Yayasan Obor Indonesia, Jakarta, 2009, hlm.177.

10 Esmi Warasih, Penelitian Socio-legal; Dinamika Sejarah dan Perkembangannya, (workshop Pemutahiran Metodelogi Penelitian Hukum, Bandung, 20-21 Maret 2006), hlm. 7-8. Lihat juga pada FX Adji Samekto, Justice Not For All :Kritik Terhadap Hukum Modern dalam Perspektif Studi Hukum Kritis, (Gents Press, Yogyakarta 2008), hlm.30-31. 
dapat mengangkat harkat martabat manusia. Model kualitatif dipilih, selain informasi yang dibutuhkan bersifat deskriptif, yakni informasi-informasi yang berbentuk uraian konsep dalam suatu dokumen dan cerita dari informan, juga ingin memperoleh informasi dari dalam (perspektif emik). ${ }^{11}$

\section{HASIL DAN PEMBAHASAN}

\section{Ide Dasar Peradilan yang berkeadilan}

Sulit untuk mengatakan bahwa kondisi dunia peradilan kita sudah bersih dari praktek gratifikasi, penyuapan dan praktek korupsi pada saat ini. Reformasi peradilan yang sering didengungdengungkan oleh Mahkamah Agung dan Komisi Yudisial belumlah menjadi kenyataan. Dunia peradilan kita masih sering membuat putusan-putusan yang kontraversial dari segi hukum dan menimbulkan kegaduhan ditengah masyarakat. Putusan-putusan yang kontraversial dan menimbulkan kegaduhan ditengah masyarakat ini bisa disebabkan oleh karena adanya kesengajaan dari hakim pembuat putusan itu sendiri, karena memang telah dipesan demikian atau bisa juga disebabkan oleh karena lemahnya penguasaan hukum baik itu hukum formil maupun hukum materil oleh hakim pembuat keputusan tersebut.

"A judge abuses power
when he takes advantage
of his judicial positionfor
personalr reasons,
including personal gain,
retaliation, or
helpingfriends or family.

11 Robert C, Bogdan and Sari Knop Biklen, Qualitative Research in education; AnIntrroduction to theory and Methods, (Allyn and Bacon Boston, 1998), hlm.4
These abuses profoundly violate the public's trust in thejudiciary. ",12

Penyalahgunaan

wewenang

(abuse of power) terjadi jika seorang hakim mengambil keuntungan dari posisinya sebagai hakim untuk kepentingan atau keuntungan dirinya sendiri, untuk tindakan balas dendam, atau untuk membantu teman-teman dan anggota keluarganya. Penyalahgunaan wewenang ini jelas sekali melanggar kepercayaan yang diberikan publik terhadap hakim tersebut. Ada adagium dalam hukum yang berbunyi ius curia novit yang berarti hakim dianggap tahu akan hukum. ${ }^{13}$ Sebagai seorang profesional dibidang hukum yang berfungsi untuk memeriksa, mengadili dan memutus perkara yang diajukan kehadapannya prinsip ius curia novit ini memang menjadi tumpuan harapan bagipara pencari keadilan. Perilaku hakim yang sering melakukan kekeliruan hukum (legal error), apalagi kalau kekeliruan hukum (legal error) sudah menjadi perilaku yang berulang-ulang, jelas menyalahi adagium ius curia novit tersebut, sehingga patutlah kalau hakim tersebut dikenakan tindakan disipliner karena berperilaku tidak profesional dan tidak pantas lagi untuk dipertahankan posisinya sebagai hakim melalui persidangan di Majelis Kehormatan Hakim.
12 New Mexico Judicial Education Center, New Mexico Judicial Ethics Handbook, UNMSchool of Law, Albuquerque, 2011, hal 4-3

13 Sudikno Mertokusumo, Hukum Acara Perdata Indonesia, Penerbit Liberty, Yogyakarta,1982, hal. 9 
Pertemuan antara hakim dengan para pihak yang berperkara tanpa kehadiran salah satu pihak lainnya (ex parte communications) apalagi kalau dilakukan diluar pengadilan, merupakan sesuatu hal yang termasuk perilaku yang tidak diperkenankan. Tetapi hal ini sering kali terjadi dalam praktek peradilan di Indonesia. Pertemuan seperti ini biasanya merupakan fase awal dari suatu persekongkolan antara hakim dengan para pihak tersebut. Peradilan yang bersih dan berwibawa akan sulit terwujud kalau perilaku ex parte communications ini dibiarkan berlanjut tanpa adanya tindakan pendisiplinan oleh Mahkamah Agungdan Komisi Yudisial.

Dalam berbagai literatur hukum banyak teori-teori yang berbicara mengenai keadilan. Salah satu diantara teori keadilan itu adalah teori etis, menurut teori ini hukum semata-mata bertujuan keadilan. Isi hukum ditentukan oleh keyakinan yang etis tentang yang adil dan tidak adil. ${ }^{14}$ Hukum menurut teori ini bertujuan untuk merealisir atau mewujudkan keadilan. Pemikiran filsafat tentang keadilan ini, terutama yang dipandang dari sudut filsafat hukum, sesuai dengan sudut pandang teori tentang tiga lapisan ilmu hukum yang meliputi dogmatik hukum, teori hukum dan filsafat hukum, sangat bermanfaat juga pada akhirnya bagi praktek hukum. Melalui pemikiran yang mendasar tentang apa yang menjadi hak yang telah menjadi buah pemikiran, dari beberapa ahli filsafat mulai dari Aristoteles sampai pada ahli filsafat masa kini, dapat

14 van Apeldoorn, Inleiding tot de Studie van het Nederlandse Recht, (Zwolle: W.E.J. Tjeenk Willink, 1995), hlm. 10. disediakan referensi bagi pengambil keputusan untuk mengarahkan dan menjalankan fungsi pengaturan dalam praktek hukum.

Masalah keadilan telah lama menjadi bahan kajian dan bahan pemikiran oleh para ahli filsafat, para politikus dan rohaniawan, namun demikian apabila orang bertanya tentang keadilan atau bertanya tentang apa itu keadilan, akan muncul berbagai jawaban dan jawaban ini jarang memuaskan hati orang yang terlibat maupun para pemikir yang tidak terlibat. Bebagai jawaban mungkin akan muncul yang menunjukkan bahwa sukar sekali diperoleh jawaban umum, apabila dikemukakan jawaban atau batasan tentang keadilan oleh suatu masyarakat maka akan terdapat semacam jawaban yang sangat beragam, sehingga dapat dikatakan bahwa berbagai rumusan tentang keadilan merupakan rumusan yang bersifat relatif. Kesulitan tersebut mendorong orang terutama kaum positivis untuk mengambil jalan pintas dengan menyerahkan perumusan keadilan pada pembentuk undang-undang yang akan merumuskannya pada pertimbangan sendiri. Pemikiran keadilan dalam hubungannya dengan hukum sejak lama sudah dikemukakan oleh Aristoteles dan Thomas Aquinus dengan mengatakan sebagai berikut ${ }^{15}$ :

Justice forms the
substance of the law, but
his heterogeneous
substance is composed of
three elements: an
individual element: the

15 Radbruch \& Dabin, The Legal Philosophi, (New York: Harvard University Press, 1950), hlm. 432. 
suum cuiquire tribuere

(individual justice): a

social element: the

changing fundation of

prejudgments upon which

civilization reposes at any

given moment (social

justice), and a political

element, which is based

upon the reason of the

strongest, represented in

the particular case by the

state (justice of the state).

Hal ini menunjukkan ada

pengaruh timbal balik antara hukum dan keadilan, yaitu bahwa hukum diciptakan berdasarkan nilai-nilai atau kaidah-kaidah moral yang adil, yang sudah ada terlebih dahulu dan yang telah hidup dalam masyarakat, jadi tugas pembentuk undang-undang hanya merumuskan apa yang sudah ada. Sedangkan dilain pihak terdapat kemungkinan bahwa perumusan hukum itu sendiri hanya bersifat memberikan interpretasi, atau memberikan norma baru termasuk norma keadilan. Tentang apa yang dimaksud dengan keadilan meliputi dua hal, yaitu yang menyangkut hakekat keadilan dan yang menyangkut dengan isi atau norma, untuk berbuat secara konkrit dalam keadaan tertentu.

Hakekat keadilan yang dimaksud di sini adalah penilaian terhadap suatu perlakuan atau tindakan dengan mengkajinya dari suatu norma. Jadi dalam hal ini ada dua pihak yang terlibat, yaitu pihak yang membuat adanya perlakuan atau tindakan dan pihak lain yang dikenai tindakan itu, dalam pembahasan ini, pihak-pihak yang dimaksud adalah pihak penguasa atau pemerintah, sebagai pihak yang mengatur kehidupan masyarakat melalui instrumen hukum, dan pihak masyarakat sebagai pihak yang tata cara bertindaknya dalam negara diatur oleh ketentuan hukum. Prinsip keadilan dalam pembentukan hukum dan praktek hukum, memperoleh kedudukan dalam dokumen-dokumen resmi tentang hak asasi manusia. Bahkan jauh sebelum dokumen-dokumen hak asasi itu dikeluarkan, prinsip keadilan telah dijadikan sebagai landasan moral untuk menata kehidupan masyarakat. Filsuf hukum alam seperti Agustinus mengajarkan bahwa hukum abadi yang terletak dalam budi Tuhan ditemukan juga dalam jiwa manusia. Partisipasi hukum abadi itu tampak dalam rasa keadilan, yaitu suatu sikap jiwa untuk memberi kepada setiap orang apa yang menjadi haknya. Prinsip tersebut mengindikasikan, inti tuntutan keadilan adalah bahwa untuk tujuan apapun, hak asasi seseorang tidak boleh dilanggar, hak asasi manusia harus dihormati, hak ini melekat pada manusia bukan karena diberikan oleh negara, melainkan karena martabatnya sebagai manusia. Hal ini berarti jika seseorang mempunyai hak atas sesuatu, orang lain juga mempunyai hak yang sama.

Pemahaman terhadap hal tersebut di atas, menunjukkan bahwa dalam kehidupan bermasyarakat dan bernegara, apa yang menjadi kepentingan bersama, akan mudah dicapai apabila masyarakat ditata menurut cita-cita keadilan. Keadilan menuntut agar semua orang diperlakukan sama, jadi keadilan merupakan suatu nilai yang mewujudkan keseimbangan antara bagian-bagian dalam masyarakat, antara tujuan pribadi dan tujuan bersama. Hal ini menunjukkan 
bahwa salah satu wujud cita-cita hukum yang bersifat universal adalah tuntutan keadilan. Soal bagaimana menentukan apakah hukum itu adil atau tidak, tidak tergantung atau tidak diukur dari kriteria obyektif keadilan, melainkan diukur dari apa yang oleh masyarakat dianggap adil. Untuk memahami hukum yang mencerminkan rasa keadilan masyarakat, terlebih dahulu harus dipahami makna hukum yang sesungguhnya. Menurut pandangan yang dianut dalam literatur ilmu hukum, makna hukum itu ialah mewujudkan keadilan dalam kehidupan manusia. Makna ini akan tercapai dengan dimasukkannya prinsip-prinsip keadilan dalam peraturan hidup bersama tersebut. Hukum yang dimaksud di sini adalah hukum positif yang merupakan realisasi dari prinsip-prinsip keadilan.

Bertolak dari pemikiran yang demikian, pengaturan hak dan kebebasan masyarakat dengan menggunakan kriteria keadilan, menunjukkan bahwa di dalam diri manusia, ada perasaan keadilan yang membawa orang pada suatu penilaian terhadap faktor-foktor yang berperan dalam pembentukan hukum. Keinsyafan akan perasaan keadilan ini bukan hanya dimiliki oleh warga negara tapi juga oleh penguasa. Oleh karena itu, dengan dibangun di atas prinsip-prinsip keadilan, maka keadilan itu dapat disebut sebagai prinsip hukum atau ide hukum. Hal ini sesuai dengan ajaran Immanuel Kant yang mengatakan bahwa keadilan itu bertitik tolak dari martabat manusia. Dengan demikian pembentukan hukum harus mencerminkan rasa keadilan dan bertujuan untuk melindungi martabat manusia. Keadilan merupakan prisip normatif fundamental bagi Negara. ${ }^{16}$ Atas dasar hal tersebut, kriteria prinsip keadilan, merupakan hal yang mendasar dan bersifat fundamental, sebab semua negara di dunia ini selalu berusaha menerapkan prisip-prinsip keadilan dalam pembentukan hukumnya. Prinsip keadilan mendapat tempat yang istimewa dalam seluruh sejarah filsafat hukum. Dalam konsep negara-negara modern penekanan terhadap prinsip keadilan diberikan dengan menyatakan bahwa tujuan hukum yang sebenarnya adalah untuk menciptakan keadilan dalam masyarakat.

Beberapa teori tentang keadilan seperti yang dikemukakan oleh Stammler, Radbruch dan Kelsen menitikberatkan keadilan sebagai tujuan hukum. Dengan demikian dapat disimpulkan bahwa hukum yang mewujudkan keadilan itu mutlak diperlukan dalam kehidupan berbangsa dan bernegara, tanpa adanya hukum hidup manusia menjadi tidak teratur dan manusia kehilangan kemungkinan untuk berkembang secara manusiawi.

Teori lain yang berbicara tentang keadilan adalah teori yang dikemukakan oleh John Rawls. ${ }^{17}$ Dalam teorinya dikemukakan bahwa ada tiga hal yang merupakan solusi bagi problema keadilan. Pertama prinsip kebebasan yang sama bagi setiap orang (principle of greatest equal liberty), tentang hal ini dirumuskan oleh John Rawls sebagai

16 Franz Magniz Suseno, Etika Politik, (cetakan ketiga) (Jakarta: Gramedia, 2003), hlm. 334.

17 John Rawls, Teori Keadilan Dasar-dasar Filsafat Politik Untuk Mewujudkan Kesejahteraan Sosial Dalam Negara, (judul asli A Theory of Justice), Terjemahan Uzair Fauzan dan Heru Prasetyo, (Yogyakarta: Pustaka Pelajar, 2006), hlm. 502. 
berikut: Each person is to have an equal right to the most extensive basic liberty compatible with a semilar liberty of thers. Rumusan ini mengacu pada rumusan Aristoteles tentang kesamaan, oleh karenanya juga kesamaan dalam memperoleh hak dan penggunaannya berdasarkan hukum alam. Rumusan ini inhern dengan pengertian equal yakni sama atau sederajat diantara sesama manusia. Usaha memperbandingkan ini juga secara tidak langsung merupakan pengakuan atau konfirmasi bahwa manusia selalu hidup bersama yang menurut Aristoteles disebut sebagai makhluk sosial, sehingga penentuan hak atau keadilan yang diterapkan adalah keadilan yang memperhatikan lingkungan sosial atau dengan kata lain harus merupakan keadilan sosial.

Prinsip ini mencakup kebebasan berperanserta dalam kehidupan politik, kebebasan berserikat dan berbicara termasuk kebebasan pers dan kebebasan beragama. Kedua prinsip perbedaan (the difference principle), yang dirumuskannya sebagai berikut: Social and economic inequalities are to be arranged so that they are bot (a) reasonably expected to be to everyone's advantage, and (b) attached to positions and office open to all. ${ }^{18}$ Rumusan ini merupakan modifikasi atau imbangan terhadap rumusan pertama yang menghendaki persamaan terhadap semua orang, modifikasi ini berlaku apabila memberi manfaat kepada setiap orang. Selain itu rumusan ini juga nampak ditujukan untuk masyarakat modern yang sudah memiliki tatanan yang lengkap,

$18 \quad$ Ibid, hlm. 303. meskipun maksudnya adalah untuk memberi pemerataan dalam kesempatan kerja atau memberi peranan yang sama dan merata, akan tetapi bagaimana pun juga sudah terlihat perhatiannya yang sungguh-sungguh, untuk tidak melupakan dan meninggalkan orang lain yang sulit untuk memperoleh kedudukan dan kesempatan dalam kegiatan ekonomi. Jadi perbedaan sosial ekonomi, harus diatur agar memberi manfaat bagi warga yang kurang beruntung. Ketiga prinsip persamaan yang adil untuk memperoleh kesempatan bagi setiap orang (the principle of fair equality of opportunity), yaitu ketidaksamaan ekonomi harus diatur sedemikian rupa agar memberi kesempatan bagi setiap orang untuk menikmatiknya.

Prisip persamaan ini lebih lanjut dikemukakan oleh W. Friedmann ${ }^{19}$ sebagai berikut:

"In a formal and general sense equality, is a postulate of justice. Aristoteles "distributive justive" demands the equal treatment of those equal before the law. This like any general formula of justice is however, applicable to any form of government or society; for it leaves it to a particular legal order to determine who are equal berfore the law... Equality in rights, as postulated by the extention of individual rights, ini principle, to all

19 W. Friedmann, ,The State and The Rule of Law in Mix Economy, (London: Steven \& Son, 1971), hlm. 385 . 
citizens distinct from a

priveleged minoritiy"

Pada pokoknya pandangan yang

dikemukakan Friedman tersebut mengandung dua pengertian. Menggaris bawahi prinsip Indonesia adalah negara yang berdasarkan atas hukum, UUD 1945 sebagai hukum dasar menempatkan hukum pada posisi yang menentukan dalam sistem ketatanegaraan Indonesia. Dalam kaitan itu, konsep kenegaraan Indonesia antara lain menentukan bahwa pemerintah menganut paham konstitusional, yaitu suatu pemerintahan yang dibatasi oleh ketentuan yang temuat dalam konstitusi. Pada negara yang bersistem konstitusi atau berdasarkan hukum dasar, terdapat hirarki perundangan, dimana UUD berada di puncak piramida sedangkan ketentuan yang lain berada di bawah konstitusi. Konstitusi yang demikian ini dikenal dengan "stufenbau theory" Hans Kelsen.

Indonesia juga mengenal tata urutan perundang-undangan menurut Stufenbau mengenai Teori Hans Kelsen. Hal ini dapat dilihat dalam Tap MPRS No. XX/MPRS/1966 Tentang memorandum DPR-GR Mengenai Sumber Tertib Hukum RI dan Tata Urutan Perundang-undangan. Tap ini kemudian dicabut dengan Tap MPR No. III/MPR/2000 Tentang Sumber Hukum dan Tata Urutan Peraturan perundangundangan. Ketetapan MPR No.III/2000 ini, terdapat perbedaan dengan Tap MPRS No. XX/MPRS/1966 tentang sumber hukum dan tata urutannya. Jika pada Tap MPRS No. XX/1966 sumber tertib hukum itu dimana Pancasila merupakan sumber dari segala sumber hukum yang perwujudannya terdiri dari :
Proklamasi 17 Agustus 1945, Dekrit Presiden 5 Juli 1959, UUD 1945 (Proklamasi) dan Supersemar 1966, maka di dalam Tap MPR No. III/MPR/2000 sumber hukum terdiri dari Pancasila dan UUD 1945. Begitu pula dengan tata urutan perundang-undangan terjadi perubahan, pada Tap MPRS No. XX/MPRS/1966 posisi Undang-undang terjadi perubahan, pada Tap MPRS No. XX/MPRS/1966 posisi Undang-undang sederajat dengan Peraturan Pemerintah Pengganti Undang-undang (Perpu), sedangkan Tap MPR No. III/MPR/2000 Perpu berada di bawah Undang-undang, dan peraturan daerah merupakan salah satu urutan perundang-undangan yang semula pada Tap MPRS No.XX/MPRS/1966 hanya merupakan peraturan pelaksana. Selanjutnya mengenai tata urutan dan pembentukan peraturan perundang-undangan dimuat dalam UU No. 10 Tahun 2004 dan kemudian diganti dengan UU No. 12 Tahun 2011, dari beberapa ketentuan tersebut ada satu persamaan yaitu bahwa semua peraturan hukum yang berlaku tidak boleh bertentangan dengan ketentuan hukum yang lebih tinggi sesuai dengan tata urutan perundang-undangan.

Mengikuti pemikiran Hans Kelsen timbul pertanyaan tentang apa yang menjadi Grundnorm dari peraturan atau hukum Indonesia. Dalam banyak literatur, jelas dikemukakan bahwa Pancasila adalah Grundnorm atau norma dasar, yang merupakan sumber dari segala sumber hukum yang berlaku dan yang akan diberlakukan di Indonesia. Hal ini dapat dilihat dari pandangan yang mengatakan bahwa Pancasila berkedudukan sebagai landasan unsur 
konstitutif dan regulatif, sebagai Grundnorm sumbernya dari segala sumber hukum dan landasan filosofis dari bangunan hukum nasional, dan pelbagai manifestasi budaya Indonesia yang memancarkan dan menghadirkan "Geislichen Hintergrund" yang khas. ${ }^{20}$ Dengan demikian hukum tidak terlepas dari nilai yang berlaku di masyarakat, bahkan dapat dikatakan bahwa hukum itu merupakan pencerminan nilai-nilai yang berlaku dalam masyarakat. Hukum yang baik adalah hukum yang sesuai dengan yang hidup dalam masyarakat. Ini berarti bahwa hukum positif Indonesia bersumber pada nilai, yaitu nilai-nilai yang terkandung dalam Pancasila yang merupakan asas kerohanian negara Indonesia. Jika konsep Grundnorm menurut teori hukum murni Hans Kelsen, dihubungkan dengan Pancasila sebagai norma dasar dalam pembentukan hukum Indonesia. Sangat sulit untuk menempatkan atau bahkan tidak mungkin memposisikan teori hukum murni tersebut untuk menafsirkan Pancasila sebagai Grundnorm. Alasannya, dilihat dari sudut pandang teori hukum, apa yang dikemukakan oleh Hans Kelsen dengan teori hukum murni, secara tegas memisahkan hukum dengan moral. Hal ini dapat dilihat dari teori Kelsen yang mengatakan; suatu analisis tentang struktur hukum positif yang dilakukan seeksak mungkin, suatu analisis yang bebas dari semua pendapat etik atau politik mengenai nilai. ${ }^{21}$ Pancasila

20 Padmo Wahyono, Indonesia Negara Berdasarkan Atas Hukum, (Jakarta:Ghalia Indonesia, 1999), hlm. 214.

21 C.K. Allen, Law in the Making, (New York: Harvard University Press, 1994), hlm. 52. sebagai pandangan hidup, sebagai sumber dari segala sumber hukum atau sebagai asas kerohanian sarat dengan nilai moral. Oleh karena itu teori hukum murni tidak mungkin menjelaskan Pancasila sebagai Grundnorm.

Formulasi yang demikian ini mengandung arti bahwa peraturan perundang-undangan, mengandung norma hukum yang didalamnya terdapat patokan penilaian dan patokan tingkah laku. Patokan penilaian ini tidak hanya terbatas pada macam-macam nilai, akan tetapi merupakan satu kesatuan atau keterpaduan yang disebut dengan sistem penilaian. Melalui sistem penilaian ini, dapat dirumuskan petunjuk tingkah laku, tentang perbuatan apa saja yang mesti dilakukan dan yang harus ditinggalkan. Penilaian terhadap tingkah laku manusia bukan merupakan penilaian yang berdiri sendiri, melainkan merupakan bagian dari suatu ide yang lebih besar, yaitu ide tentang masyarakat yang dicita-citakan.

Melalui hukum progresif, maka seharusnya perilaku koruptif di pengadilan tidak terus berkembang biak menjadi memburuk. Ide hukum progresif menjadi penting dan relefan di tengah maraknya mafia peradilan dan merosotnya kepercayaan masyarakat terhadap kinerja lembaga peradilan. Hukum selalu identikan dengan positivistik di pengadilan melalui teks yang tertulis dengan menihilkan peranan manusia, tetapi dalam realitasnya teks tidak dapat menjawab permasalahan telah menunjukkan hukum tidak dapat dipercaya dalam kehidupan sesungguhnya, termasuk lembaga peradilan. Didalam pandangan ke depan hukum tertulis itu baru dalam tahap janji- 
janji saja, baru dapat menjadi hukum apabila dijalankan dengan sungguh, sepenuh hati dan dengan hati nurani dijalankan penegak hukum dan ditaati oleh masyarakat, maka hukum itu hidup didalam masyarakat. Gambaran terlihat di kelembagaan pengadilan sebagai bahan mempelajarinya. Pengadilan bersih, obyektif dan tidak berpihak menjatuhkan putusan, maka pencari keadilan mendapatkan keadilan yang diharapkan.

\section{Pendekatan Kontrol Sistem Peradilan Pidana sebagai Alternatif Mendistribusikan Keadilan}

Peradilan pidana merupakan
bagian penting dalam $r$ usaha
penanggulangan kejahatan dengan sarana
hukum pidana. Peradilan pidana bekerja
dalam suatu sistem penegakan hukum
pidana yang bersifat terpadu,
menitikberatkan pada keterpaduan
sistem, sehingga lazim disebut Sistem
Peradilan Pidana. Keterpaduan dalam
sistem peradilan pidana dimaksudkan
agar proses peradilan berjalan secara
efektif dan efisien, saling menunjang
antar penegak hukum dalam menemukan
hukum dan menerapkan yang tepat untuk
menjamin kepuasan pencari keadilan
yaitu mewujudkan keadilan dalam
kesadaran kenyataan r hukum
masyarakat. ${ }^{22} \quad$
Apabila peradilan pidana dipahami dariaspek pendekatan sistem hukum, maka bekerjanya peradilan pidana sangat teragantung dari sinkronisasi dan harmonisasi dari

22 Hafrida, "Sinkronisasi Antar Lembaga Penegak hukum dalam Mewujudkan Sistem Peradilan Pidana yang Terpadu", Jurnal Hukum Forum Cendekia, Vol 18 No. 2Oktober 2008, hlm. 66 komponen peradilan pidana, yaitu sub sistem penyidikan, sub sistem penuntutan, sub sistem pengadilan dan sub sistem pelaksanaan putusan pengadilan yaitu Lembaga Pemasyarakatan. Perilaku penegak hukum yang menerima uang suap merupakan tindakan merusak komponen kultur hukum (legal culture), akibatnya penegak hukum yang mengabaikan asasasas peradilan yang baik, juga merusak sistem interaksi yang sudah baku standarnya, yang terjadi kemudian adalah carut marut penegakan hukum pidana.

Sistem peradilan pidana sering diartikan secara sempit sebagai sistem pengadilan yang menyelenggarakan keadilan atas nama negara atau sebagai mekanisme untuk menyelesaikan suatu perkara/sengketa. Dalam arti sempit, peradilan pidana hanya melihat aspek struktural (yaitu "system of court" sebagai institusi) dan hanya melihat aspek kekuasaan mengadili dan menyelesaikan perkara (administration justice/mechanism for the resolution of disputes). Peradilan pidana sebagai sistem mencakup dua aspek, yaitu aspek struktur institusi yang melibatkan beberapa instansi penegak hukum dan aspek nilai, yaitu asas-asas penegakan hukum pidana yang tercakup dalam due process oflaw. Interaksi antar instansi penegak hukum dalam mekanisme proses peradilan mencakup rantai kewenangan sistem peradilan pidana. Secara konseptual, inti dan arti penegakan hukum terletak pada kegiatan menyerasikan hubungan nilai-nilai yang dijabarkan dalam kaidah-kaidah yang mantab dan mengejawantah serta sikap tindak sebagai rangkaian penjabaran nilai 
tahap akhir, untuk menciptakan, memelihara dan mempertahankan kedamaian dan ketertiban masyarakat. ${ }^{23}$ $\begin{array}{cccr} & \text { Substansi } & \text { nilai merupakan } \\ \text { fondasi } & \text { filosofis } & \text { dalam rangka }\end{array}$ memperkuat asas-asas penegakan hukum yang adil (due processof law), sebaliknya konsep penegakan hukum yang lebih menekankan pada pendekatan sistem yang kaku dan prosedural, mengejar tujuan tetapi mengabaikan aspek kemanusiaan dan tujuan hukum yaitu mewujudkan keadilan. Hukum adalah alat yang digunakan untuk menegakkan nilai-nilai kemanusiaan, bukan hanya sebatas pemenuhan prosedur hukum yang kaku, tetapi untuk menjunjung tinggi nilai kemanusiaan, karena sesungguhnya hukum adalah untuk manusia. ${ }^{24}$

Penegakan hukum pidana yang dijalankan berdasarkan konsep penegakan hukum sama dengan penegakan undang-undang, memberikan peluang penyalahgunaan kekuasaan, yaitu tindakan hukum yang sewenangwenang (arbitrary process of law). Hukum dijalankan dalam mekanisme dan prosedur yang kaku, mengabaikan unsur nilai kemanusiaan. Pertimbangan kemanusiaan menjadi berkurang, umumnya pada tindakan hukum

23 Hibnu Nugroho, "Optimalisasi Penegakan Hukum Dalam penanggulangan Kejahatan Global di Indonesia", Jurnal Media Hukum, UMY Yogyakarta Vol XVII No 4 Desember 2007, hlm. 517

24 Secara garis besar bekerjanya hukum di masyarakat ditentukan beebrapa faktor, yaitu faktor juridis normatif (UU), penegak hukum, faktor juridis sosiologis, yaitu aspek ekonomi dan kultur hukum. Lihat YohanesSuhardin. 2009. Penegakan Hukum yang Berkeadilan Sosialdan Berdimensi HAM (Studi Penggusuran Kelompok Marginal), Jurnal Media Hukum UMY Yogyakarta, Vol 16No.3 penggunaan upaya paksa seperti penangkapan dan penahanan. Penegakan hukum berdasarkan wewenang tidak keliru, tetapi menjadi kurang manusiawi apabila dipergunakan secara berlebihan. Untuk meningkatkan kualitas penegakan hukum yang berorientasi pada spirit due process of law, maka perlu melakukan reformasi peradilan pidana. Reformasi sistem penegakan hukum pidana yang bersifat integral, dimulai dengan melakukan reformasi dan rekonseptualisasi "kekuasaan kehakiman" dan "desain penerapan kekuasaan kehakiman". Kekuasaan kehakiman di bidang hukum pidana bukan hanya diwujudkan dalam "kekuasaan mengadili", tetapi diwujudkan/diimplementasikan dalam keseluruhan proses peradilan pidana, yaitu tahap penyidikan, penuntutan, sidang pengadilan dan pelaksanaan putusan pengadilan. Keseluruhan proses peradilan pidana yang melibatkan lembaga-lembaga penegak hukum tersebut lazim dikenal dengan istilah "sistem peradilan pidana yang terpadu" (integrated criminal justice system).

Menata ulang "kekuasaan kehakiman" dalam proses peradilan pidana menjadi penting, karena pemberian kekuasaan kehakiman yang hanya tertuju kepada pengadilan menjadi titik lemah dalam sistem peradilan itu sendiri. Hal ini berkaitan dengan definisi dan ruang lingkup "kekuasan kehakiman" sebagaimana tersebut dalam Pasal 1 ayat (1) UU No. 48 Tahun 2009 Tentang Kekuasaan Kehakiman, sebagai kekuasaan negara yang merdeka untuk menyelenggarakan peradilan guna menegakkan hukum dan keadilan. 
Kekuasaan kehakiman sebagai kekuasaan negara yang merdeka, akan sangat menentukan kualitas, kredibilitas, dan integritas keseluruhan proses peradilan. Lembaga yang mempunyai kekuasaan kehakiman hanya lembaga pengadilan, maka hanya lembaga pengadilan yang bersih dan kebal (clean and immune) dari segala campur tangan pihak kekuasaan ekstra judisial, sedangkan lembaga penyidik, penuntut umum, dan lembaga pemasyarakatan menjadi rentan dan rawan intervensi kekuasaan ekstra judicial dan penyalahgunaan kekuasaan publik (illegal abuse of public power). Usaha mengatasi kelemahan hukum dalam pengaturan kekuasaan kehakiman menurut Barda Nawawi Arief, ${ }^{25}$ ada dua kemungkinan yang dapat ditempuh. Pertama, membuat perundang-undangan baru atau merevisi ketentuan perundangundangan yang berlaku saat ini dengan menegaskan pejabat mana yang dipandang sebagai "pejabat pengendali" itu. Kedua, kekosongan perundangundangan itu diisi lewat yurisprudensi. Dalam hal pertama, bahwa Mahkamah Agung-lah yang ditetapkan sebagai "pejabat pengendali". Alasannya, menurut Pasal 24 UUD 1945, Mahkamah Agung-lah yang melaksanakan fungsi "Kekuasaan Kehakiman". Pengertian "kekuasaan kehakiman" seyogianya tidak hanya diartikan sebagai "kekuasaan mengadili", tetapi lebih luas lagi, yaitu sebagai "kekuasaan untuk menegakkan hukum dan undang-undang. Apabila kekuasaan kehakiman diartikan secara luas, maka

25 Barda nawawi Arief, 1998, Beberapa Aspek Penegakandan Pengembangan Hukum Pidana, Bandung: PT. Citra Aditya Bakti, hlm. 33
Mahkamah Agung tidak hanya berfungsi mengawasi penegakan hukum oleh badan-badan pengadilan, tetapi juga mengawasi seluruh proses penegakan hukum yang dilakukan mulai proses penyidikan, penuntutan, sampai pada putusan pengadilan dijatuhkan dan dilaksanakan/dieksekusi.

Penataan kembali "kekuasaan kehakiman" dalam rangka menjalankan "kekuasaan penegakan hukum", yang memberikan kedudukan Mahkamah Agung sebagai otoritas tunggal dalam penyelenggaraan kekuasaan kehakiman yang merdeka dan mandiri, mampu mengintegrasikan keseluruhan lembaga penegak hukum dalam menjalankan sistem peradilan pidana. Menempatkan Mahkamah Agung menjadi "pengawas dan pengendali puncak/tertinggi (the top leader atau the top law enformcement officer) dari keseluruhan proses penegakkan hukum pidana (mulai tahap penyidikan, penuntutan, sampai pada proses mengadili, menjatuhkan putusan/pidana dan eksekusi pidana). Adanya "pengendali puncak/tertinggi“" ini merupakan konsekuensi logis dari manajemen SPP yang terpadu (integrated criminal justice system). Tanpa adanya pengendali puncak, dikhawatirkan bekerjanya SPP bersifat "fragmentaris" atau "instansi sentries". ${ }^{26}$ Nilai-nilai dasar akuntabilitas publik dalam penegakan hukum, khususnya dalam upaya pemberantasan mafia peradilan, meliputi prinsip-prinsip, pertama adalah access to justice (akses kepada keadilan), pada proses hukum dan putusan; kedua adalah timelines of justice delivery (standar 
waktu untuk mencapai keadilan); ketiga adalah quality of justice delivery (kualitas keadilan dari penegak hukum dan putusan hakim); dan keempat adalah independence, impartiality and fairness of the judiciary (independensi, imparsialitas juga keterbukaan dari kekuasaan peradilan); kelima adalah public trust in judiciary (kepercayaan masyarakat pada kekuasaan kehakiman/peradilan). Prinsip-prinsip diatas merupakan bagian dari arus besar globalisasi yang mensyaratkan prinsipprinsip Good Governance, seperti transparansi, keterbukaan, akuntabilitas publik, proporsionalitas dalam kegiatan organisasi.

Desain sistem atap tunggal kekuasaan kehakiman yang ditujukan pada spirit independensi peradilan tidak mempunyai arti sama sekali, bahkan terjadi distorsi makna kebebasan/independensi peradilan. Independensi peradilan bisa dijalankan dan lepas dari campur tangan kekuasaan eksekutif dan legislatif, tetapi penegak hukum tidak mampu bertahan dari godaan materi dan uang yang berlimpah. Kekuatan materi dan uang mereduksi independensi peradilan dan terjerumus dalam mafia peradilan dengan modus operandi menyalahgunakan kekuasaan (illegalab-seofpublikpower). Makna kebebasan peradilan perlu dikoreksi dalam konteksyang lebih proporsional, yaitu "keseimbangan antara prinsip kebebasan peradilan dan akuntabilitas", agar setiap produk penegakan hukum "membumi", diterima masyarakat dan dipercaya sebagai lembaga negara yang menjalankan monopoli peradilan pidana. Kondisi yang diinginkan hukum hanya dapat terwujud apabila hukum ditopang penegak hukum yang terampil, tetapi juga bermoral dan berdedikasi tinggi. ${ }^{27}$

Respon terhadap penanggulangan kejahatan. Sistem peradilan pidana menjadi perangkat hukum yang dapat digunakan dalam menanggulangi berbagai bentuk kriminalitas sebagai bagian dari upaya perlindungan masyarakat. Karakteristik demikian ini melekat pada fungsi sistem peradilan pidana sebagai sarana masyarakat untuk menahan dan mengendalikan kejahatan pada tingkat tertentu (crime containment system), serta mengurangi kejahatan dikalangan mereka yang pernah melakukan tindak pidana dan mereka yang bermaksud melakukan kejahatan, melalui proses deteksi, pemidanaan dan pelaksanaan pidana.

\section{PENUTUP}

Pertama, menata kembali ide dasar peradilan yang berkeadilan melalui rekonstruksi distribusi keadilan dalam praktek sistem peradilan pidana. Merupakan alternatif solusi sebagai penataan ide dasar sistem hukum peradilan yang terus bergerak megngikuti perkembangan peradaban, meletakan kembali nilai-nilai keadilan dalam peroses penegakan hukum melalui sistem peradila pidana merupakan sebagian dari proses pendistribusian keadilan dari lembaga peradilan.

Kedua, kontrol sistem peradilan pidana sebagai alternatif mendistribusikan keadilan, meski saat ini saling bertolak belakang anatar crime control model dan due process model saling bertolak belakang satu

27 Mahmutarom HR, "Pembangunan Hukum Nasional dalam Konteks Global”, Jurnal Masalah-Masalah Hukum, FH UNDIP, Semarang, 2006, hlm. 86. 
sama lain, dimana crime control model menekankan adanya praduga bersalah (presumption of guilty) dan due process model menekankan adanya praduga bersalah (presumption of innocence). Akan tetapi sebenarnya keduanya tidaklah bertentangan karena berlandasan filosofis yang berbeda yakni dua konsep berpikir yang berbeda, akan tetapi secara ketat dapat diterapkan menjadi sistem kontrol sistem peradilan pidana untuk memberikan keadilan.

Saran atau usulan gagasan untuk perbaikan berdasarkan permasalahan yang terpotret dalam penelitian ini yang relevan dengan pokok permasalahan. Pertama, perlu proses transplantasi hukum yang integral dan selaras dengan tatanan hukum Pancasila, melalui pembaharuan sistem hukum pidana matril dan formil untuk menyesuaikan dengan perkembangan peradaban masyarakat dalam suatu tatatan hukum tertentu.

Kedua kontrol sistem peradilan pidana, bukan merupakan hal baru dalam sistem hukum civil law sistem diperlukan formulasi yang konstruktif dan progresif dalam reformasi/pembarahan sistem peradilan pidana. Kontrol merupakan suatu yang hakiki dalam mempertahankan dan melindungi hakhak asasi manusia.

\section{DAFTAR PUSTAKA}

Abraham Blumberg, Criminal Justice, Published by Burns and MacEachern Ltd, Toronto 1970,

Barda nawawi Arief, Beberapa Aspek Penegakandan Pengembangan Hukum Pidana, Bandung: PT. Citra Aditya Bakti, 1998.

C.K. Allen, Law in the Making, New York: Harvard University Press, 1994.

Cavadino Michael dan Dignan James, The Penal Sistem An Introduction, 1997, SAGE Publication Ltd.
Franz Magniz Suseno, Etika Politik, cetakan ke-tiga .Jakarta: Gramedia, 2003.

FX Adji Samekto, Justice Not For All :Kritik Terhadap Hukum Modern dalam Perspektif Studi Hukum Kritis, Gents Press, Yogyakarta 2008.

Hafrida, "Sinkronisasi Antar Lembaga Penegak hukumdalam Mewujudkan Sistem Peradilan Pidana yang Terpadu", Jurnal Hukum Forum Cendekia, Vol 18 No. 2Oktober 2008.

Herbert Packer, The Limits of the Criminal Sanction, Stanford University Perss, Stanford Calivornia, 1968,

John Rawls, Teori Keadilan Dasar-dasar Filsafat Politik Untuk Mewujudkan Kesejahteraan Sosial Dalam Negara, (judul asli A Theory of Justice), Terjemahan Uzair Fauzan dan Heru Prasetyo, Yogyakarta: Pustaka Pelajar, 2006.

Mahmutarom HR, "Pembangunan Hukum Nasional dalamKonteks Global", Jurnal Masalah-Masalah Hukum, FH UNDIP, Semarang, 2006.

Mardjono Reksodipoetro, Sistem Peradilan Pidana Indonesia (melihat kepada kejatahan dan penegakan hukum dalam batas-batas toleransi) Pidato Pengukuhan Penerimaan Jabatan Guru Besar tetap dalam Ilmu Hukum pada Fakultas Hukum Universitas Indonesia 1993.

New Mexico Judicial Education Center, New Mexico Judicial Ethics Handbook, UNMSchool of Law, Albuquerque, 2011.

Nugroho, Hibnu, "Optimalisasi Penegakan Hukum Dalam penanggulangan Kejahatan Global di Indonesia", Jurnal Media Hukum, UMY Yogyakarta Vol XVII No 4 Desember 2007.

Padmo Wahyono, Indonesia Negara Berdasarkan Atas Hukum, Jakarta:Ghalia Indonesia, 1999. 
Radbruch \& Dabin, The Legal Philosophi, New York: Harvard University Press, 1950.

Robert C, Bogdan and Sari Knop Biklen, Qualitative Research in education; AnIntrroduction to theory and Methods, Allyn and Bacon Boston, 1998.

Soerjono Soekanto, Efektifitas Hukum dan Peran Sanksi, Remaja Karya, 1985.

Suhardin, Yohanes. 2009. Penegakan Hukum yang Berkeadilan Sosialdan Berdimensi HAM (Studi Penggusuran Kelompok Marginal), Jurnal Media Hukum UMY Yogyakarta, Vol 16No.3

Sulistyowati Irianto, memperkenalkan studi Sosiolegal dan Implikasi Metodelogisnya dalam Metode Penelitian Hukum, Konstelasi dan Refleksi, Editor Sulistyowati Irianto dan Shidarta, Yayasan Obor Indonesia, Jakarta, 2009.

Sudikno Mertokusumo, Hukum Acara Perdata Indonesia, Penerbit Liberty, Yogyakarta, 1982.

Riyanto, Sigit dan Eddy O.S. Hiariej,2001, "Fungsi Polisi Dalam Sistem Peradilan Sipil Pasca Pemisahan TNI- Polri" Mimbar Hukum, Majalah Berkala Fakultas Hukum UGM.

Romli Atmasasmita, Sistem Peradilan Pidana, Perspektif Eksistensialsime, Binacipta Bandung, 1996.

Uladi,Hak Asasi Manusia: Hakekat, Konsep Dan ImplikasinyaDalam Perpektif Hukum dan Masyarakat, Refika Aditama, 2005.

van Apeldoorn, Inleiding tot de Studie van het Nederlandse Recht, Zwolle: W.E.J. Tjeenk Willink, 1995.

Warasih, Esmi, Penelitian Socio-legal; Dinamika Sejarah dan Perkembangannya, (workshop Pemutahiran Metodelogi Penelitian Hukum, Bandung, 20-21 Maret 2006),
W. Friedmann, The State and The Rule of Law in Mix Economy, London: Steven \& Son, 1971. 